\title{
Local Religiosity in the Context of Migration \\ The Cases of the Greek Catholics from Žumberak in Croatia and the Orthodox Christian Serbs in Eastern Serbia
}

DOI 10.17234/9789531756525.12

Petko Hristov

Institute of Ethnology and Folklore Studies with Ethnographic Museum, Bulgarian

Academy of Sciences

Moskovska Str. 6A, 1000 Sofia, Bulgaria

petko.hristov@iefem.bas.bg

Violeta Periklieva

Institute of Ethnology and Folklore Studies with Ethnographic Museum, Bulgarian

Academy of Sciences

Moskovska Str.6A, 1000 Sofia, Bulgaria

violeta.periklieva@iefem.bas.bg

Considering two case studies, this article presents the functioning and attitude toward local religiosity in the context of migration. The first case study examines permanent internal migration of the Greek Catholics from the region of Žumberak in Croatia and the second one temporary labour migrants from ex-Yugoslavia, particularly from Eastern Serbia and Western Macedonia. Searching for answers to the questions of the migrants' attitudes toward local religiosity, its role in the construction of identity and the impact of migration on it, we cannot but consider the "laws" to which these processes submit in social life.

Keywords: internal migration, external migration, labour mobility, local religiosity, identity

\section{Introduction}

7 he paper will present two case studies related to the functioning and the attitude toward local religiosity in the context of migration. The first case

L study examines permanent internal and external migration of the Greek Catholics from the region of Ž umberak in Croatia. The second one refers to temporary labour migrants (Gastarbeiters) from the former Socialist Federal Republic of Yugoslavia, particularly those from the eastern part of the Republic of Serbia and the western part of the Former Yugoslav Republic of Macedonia. We decided to compare regions with different confessional characteristics in the countries created after the break-up of the former Yugoslav federation in which a long-standing tradition 
of labour mobility presents one of its important features. In the second half of the $20^{\text {th }}$ century, these regions detached steady waves of labour migrants into big cities in Yugoslavia, as well as to Western European countries.

The study will search for answers to the following questions:

- What is the migrants' attitude toward local religiosity?

- What is the impact of migration on the local religious life in the place of origin?

- What role does local religiosity play in the construction of identity under the conditions of migration?

One of the current research problems related to migration is the changing identity of migrants. According to Fredrik Barth (1969), collective identity is a dynamic cultural construct. The mechanism of self-identification, i.e. the formation of an idea about one's own community, is not based on invariable features of that community. At the basis of the creation of this idea is the relation to other community/communities. Hence, the definition of one's own community is interactive and reflexive. The idea of one's own community is a reflection of the idea of other communities with which it enters into contact and to which it compares itself. Following Barth's concept, we could assume that cultural differences between communities are not a result of their spatial or social isolation but of their interaction; hence, we could not speak of identity in the absence of interaction. And, since the interaction is a process, identification is a process, as well - identity is not an innate and invariable feature, but a subject of construction. Life in migration, under the conditions of pan-European mobility, creates a new social context on the European continent; the opportunities of interaction increase significantly compared to the settled life in the home place which results in the construction of new multidimensional identity by the individuals and the social groups. It is precisely this fact that makes the problem of migrants' identity so relevant.

Self-identification is the sense of sharing with others a particular set of symbols which enable the members of the group to "speak the same language". And since borders (symbolic and/or political) are not impermeable but rather places of contact (Gagnon 1997: 60), the members of the communities they discriminate could also share particular symbols. This presupposes different levels of self-identification, i.e. the co-existence of many overlapping and shifting identities (ibid.: 56). These identities are part of a hierarchical system which is subject to change just like its components.

Here we would like to explain the reason why we chose to examine migratory processes in the light of religion and more precisely of local religiosity. Proceeding from Durkheim's concept of religion as a social phenomenon (Аюркем 1998) and Geertz's understanding of religion as a system of symbols which teach us to see and comprehend the world in a certain way (i.e. not only as a reflection of the social 
structure but also as a tool for its changing) (Geertz 1973: 87-125), we could argue that religion reflects society and social interests while at the same time also representing an instrument for the construction of community and meeting social interests. However, everyone attaches different meaning to the symbols and interprets them differently. Therefore, it is not the sharing of common message encoded in the symbols that constructs an idea of the society common for the members of the community, but the sharing of the symbols themselves (Cohen 1985: 16-18).

Religion provides precisely those symbols whose sharing leads to different levels of self-identification. The local perspective to religion refers to the interaction between the universal religious doctrine and its local variants typical of particular local communities. Local religiosity is here understood as what Bourdieu (1971) defines as a field of doctrines and ideas, behavioural complexes and stereotypes, specific practices and institutions that regulate them which, at different historical stages, combine in a different way. Or, according to Galya Valchinova, local religiosity includes religion in its institutional form and organization as well as various and unregulated reflections of the religious in everyday life (Въцчинова 1999: 15). Religiosity unlike religion allows us to cover activities, processes, institutions as well as the religious mentality, all of which remain latent or hidden for a long period of time (Въцчинова 2006: 19). Thus, local religiosity is understood here not so much as a belief but as a set of various religious elements (mainly but not only rituality) to which people resort and from which they choose in the process of identity construction. In this respect, local religiosity is an appropriate perspective to the problem of identity under the conditions of migration.

The basis of this study is the ethnographic fieldwork of the two authors. The empirical data on the Greek Catholic community of Žumberak were collected in 2001 and 2012. In 2001, Petko Hristov visited the villages of Sošice, Visoće, Plavci and Kašt and interviewed local people as well as the local priest Željko Pajić and Bishop Nikola Kekić. In 2012, Violeta Periklieva conducted fieldwork in several villages in the region of Žumberak (Sošice, Stojdraga, Budinjak, Kravljak and Kalje) as well as in some of the cities with Greek Catholics from Žumberak (Zagreb and Samobor), interviewing local people as well as church representatives (Mile Vranešić, Danijel Vranešić, Robert Rapljenović and Bishop Nikola Kekić). Field research in Eastern Serbia (Trgovište near Knjaževac, and Halovo near Zaječar) and Western Macedonia (Vevčani) was conducted by Petko Hristov in 2001 and 2012. It was part of a bigger ethnographical and historical research conducted in the regions of Tran in Bulgaria, Pirot and Knjaževac in Serbia, and Kriva Palanka and Kratovo in the Republic of Macedonia. This region is known in the literature as Shopluk - a denotation with unclearly defined borders and cultural specifics (Христов 2004: 67-82). As a basis for comparison, the authors use materials from fieldwork conducted in 2005 by Petko Hristov (see Hristov 2010: 141-150) in another border region in the heart 
of the Balkans, famous in the past for its ethnic and religious diversity and for the mass labour mobility (seasonal and temporary) of its male population - the Miyak region in Northwestern Macedonia, where the state borders of Albania, the Republic of Macedonia and the newly-proclaimed Republic of Kosovo converge nowadays.

In view of the specifics of the theme, the authors adopted the model of so-called multi-sited ethnography to a great extent in organizing and conducting the ethnographic fieldwork. It was first presented by George Marcus (1995) and oriented towards the study of global processes and the increasing interrelations between people. Multi-sited ethnography gives an opportunity for analytical study of transnational processes, of the movements of people and ideas whose dissemination includes multiple locations. In contrast to the classical ethnographic fieldwork when the researcher usually spends a longer period of time in one specific location, in the case of multi-sited ethnography the researcher moves in many different spaces following the subject of the study. The spaces could be geographical, social or virtual and depend on the specific thing which the researcher chose to trace.

Although, in its classic form, it is applied to the study of migration processes, the adoption of multi-sited ethnography in studying processes of identity construction on various levels also has its advantages. During our fieldwork, we tried to adapt the model to our study using two main techniques: tracing the movement of the subjects (the people), and tracing the dissemination of particular symbols and devices of communal consolidation and self-identification.

In the case of the border studies, tracing the movement of people across the border proved to be very useful. It allows the researcher to better understand the reasons for the crossing of the border and its frequency, to observe the contacts of the subject on the other side of the border, his/her attitude in the context of being abroad, etc. In case there is no opportunity to follow the people themselves, the researcher could trace their social networks across the border: to visit their relatives, friends, business partners, etc. Tracing the movement of people, members of the researched communities, especially during religious holidays, allows registering their religious practices and selecting those which eventually function as mechanisms for self-identification of the respective community. At the same time, the specific spatial characteristics of the movement of people (the places they visit) when observing the religious practices as well as the type of other participants (their affiliation to particular community) give information about various social networks in which these people take part, as well as about the levels of their self-identification (local, regional, national, confessional, etc.). Tracing (or rather accompanying) one or more particular persons, members of the researched community, allows observing different ways of self-identification according to the context, too.

On the other hand, the model of multi-sited ethnography allows tracing the dissemination of symbols and mechanisms which were already selected by the researcher and which function as identification markers. Determining their presence or 
absence in various geographical or social spaces provides information about the type and scope of their functions and about different forms of their usage. In addition, the spatial movement and the shifting of different locations allow the researcher to ask different groups of people within the community the same set of guiding questions, and to compare or analyse the different answers and points of view. All this creates preconditions for an overall picture of the processes of communication and identification in the case of migration.

\section{Permanent migration of the Greek Catholics from Žumberak in Croatia}

The region of Žumberak is located in the hilly northwest part of Croatia, on the border with Slovenia. From the $12^{\text {th }}$ century, the fiefs in Žumberak gradually fell into the hands of Austrian counts and princes. In the $16^{\text {th }}$ century, with the Ottoman Empire gradually conquering the Balkans, the Ottoman raids in Žumberak multiplied and the local population began to migrate leaving the region pretty deserted. In the $16-17^{\text {th }}$ century, the so-called Military Frontier (Vojna krajina) was established in the border regions of the Habsburg Empire. The population with variegated ethnical structure that had run away from the devastations of the Ottoman invaders was settled in the regions forming the Military Frontier. The region of Žumberak was also part of the Military Frontier. The district of Žumberak was one of the first regions of the Military Frontier settled in the 1530s and 1540s with mainly Orthodox population leading the nomadic-military way of life. In the Austrian sources, they were called "Valachi Turcorum", "Valachi", "Rasciani Voskoky", "Valachi Uzkoky", "Pribegi" and "Vsskhokhen" (Kaser 1997a: 55), and in some other sources "Serbs" or "Rascians" (cf. Mal 1924). In the late 16" and the early $17^{\text {th }}$ century, there were several attempts of forcing Catholicism upon the Orthodox population settled in the Military Frontier. However, the imposing of Catholicism in the second half of the $18^{\text {th }}$ century significantly influenced today's confessional situation in Žumberak. In the remaining regions of the "frontier", Catholicism did not succeed to take deep root. Yet, after the 1770s, a union with the Pope was forced upon the Orthodox population in Žumberak. Thus, there were 3,879 Greek Catholics registered in five parishes in 1820 (Kaser 1997b: 185-186).

The natural growth of population which followed the demilitarization of the region in 1871, as well as the partition of the land related to the disintegration of the joint family households, led to the lack of agricultural land and pasture-grounds. This resulted in disturbance of the economic stability of the region. Consequently, in the 1880s, the population gradually began to migrate, first to bigger cities in the country and later even abroad (mainly to the USA). ${ }^{1}$

For the migration of the Greek Catholics from Žumberak to Cleveland, Ohio, USA see: Čizmić and Hranilović 1990. 
Migration processes that had started among the Greek Catholic community in Žumberak as early as the late $19^{\text {th }}$ century, continued throughout the $20^{\text {th }}$ century. The first migration flow was oriented mainly toward the countries in North and South America and continued until World War I. In this period, migration of $40 \%$ of the population only in the vicinity of the village of Radatovići was registered (Muraj 1989: 65). The second flow took place in the interwar period and was oriented mainly toward European countries. After World War II, most migratory movements were directed towards larger Croatian cities - Zagreb, Jastrebarsko, Samobor and Karlovac (Čapo Žmegač 2007: 90), but also to Slovenia and other Yugoslav republics. If in 1820 there were 3,879 Greek Catholics registered in Žumberak, the census of $2001^{2}$ showed that the total number of the Greek and the Roman Catholics in the region was already only 1,185. The depopulation of the region went hand in hand with another process - the ageing of the remaining local population. The lack of subsistence forced the young active population to look for opportunities in big cities in the country. Thus, at the beginning of the $21^{\text {st }}$ century, because of the internal migratory processes, the Greek Catholic community from Žumberak has been concentrated in three main Croatian cities - Zagreb, Samobor and Jastrebarsko, but also in Metlika in Slovenia. At the same time, external migration dispersed many Greek Catholics from Žumberak all over the world but mainly in Western Europe and Northern America. As a result of migration processes that lasted for over a century, the number of the total population (Greek and Roman Catholics) in Žumberak amounts to 872 (according to the census of $2011^{3}$ ). At the same time, life in migration, the aspiration for integration in the new environment, marriages with Roman Catholics and the feeling of discomfort or even fear caused by the different confessional affiliation ${ }^{4}$ is the reason why, in large Croatian cities, some of the Greek Catholic migrants neglect their specific religious rituality and the others refrain from making it public. However, the dispersion and depersonalization of the Greek Catholic community in Žumberak has caused some reverse processes consolidation and self-identification at the regional and national level. ${ }^{5}$

Today, there is a tendency toward the "virtualization" of the Greek Catholic community of Žumberak. The Greek Catholics live dispersed, but they are beginning to construct local community consciousness without actually having a common locality. As a whole, the construction of identity at a confessional level pretty much

\footnotetext{
2 https://www.dzs.hr/Hrv/censuses/Census2001/census.htm (last access 16 November 2017).

3 https://www.dzs.hr/Hrv/censuses/census2011/censuslogo.htm (last access 16 November 2017).

4 For more information on the problems of the Greek Catholics in Croatia caused by their different (compared to the rest of the Croats) confessional affiliation see: Periklieva and Hristov 2013.

5 On the process of self-identification of the Greek Catholic community from Žumberak on the national level see: Periklieva and Hristov 2013.
} 
overlaps with this at a local level, i.e. there is a certain level of equality between Greek Catholic, Žumberčanin and uskok. In the last several years, the community scattered in Croatia and the world has created its own spaces on Internet. At the moment, there is a website ${ }^{6}$ and two groups on Facebook (I Love Žumberak ${ }^{7}$ and Moj $\check{Z}$ umberak/My $\check{Z}$ umberak ${ }^{8}$ ) which are the main forms of everyday communication of the community on Internet. Although their names do not refer to religious affiliation and their administrators define them as open to anyone related to the region of Žumberak in one way or another, the main active members of these groups and sites are Greek Catholics. Moreover, these spaces on Internet are the main channel for "advertising" Greek Catholic religious, cultural and social initiatives and for sharing everything that is important for the community. Through them, the migrated Greek Catholics (especially those abroad) search and establish contact with relatives, study their genealogy, get to know their origin and the culture of their ancestors, and restore their connections with the community and their place of birth. In this way, the virtual space becomes a new form of common locality for the "virtual" community of Žumberak.

However, a pronounced process among this "virtual" community is "returning". The migrated Greek Catholics from Žumberak return to their places of birth periodically or permanently. The latter usually happens when people retire. Many of those who have already returned, as well as those who plan to do so, share the feeling of aspiration and need since the very beginning of their migration (this applies to the first generation of migrants) or long ago. Periodical returning, however, is more important in terms of the topic of local religiosity. Many people come back to their birth places for religious feasts, patron saint's days of the churches and chapels in the region (proštenje), for pilgrimages, Saturday feasts for the dead, weddings, christenings, etc. which gather the otherwise "virtual" community in one place. The observation of many of these religious feasts and rituals by a community consisting mainly of periodically returning migrants results in their transformation. Gradually, the integrative function of the patron saint's day of the churches began to expand, constructing a community based on the regional and confessional principle rather than on the village principle. The family character (their worshiping on a family basis) of the chapels (kapelica) also receded into the background and since there are no remaining heirs to run them, owing to migration processes, today some chapels are desolate and the others are being cared for and worshipped by the whole community.

The process of depopulation that is still happening in Žumberak, on the one hand, and the process of periodical returning to the places of origin, on the other,

6 http://mojzumberak.com/ (last access 16 November 2017).

7 https://www.facebook.com/groups/17240392943 (last access 16 November 2017).

8 https://www.facebook.com/groups/204828039645938 (last access 16 November 2017). 
give rise to an "extreme" form of celebration of patron saint's days in deserted villages. ${ }^{9}$ This is the case of the village of Kravljak. Until June 2012, there were four old people living in the village. After a criminal incident in the village, Kravljak was deserted within only several days. Nevertheless, next year, those who had left the village, their heirs as well as people originating from other villages in Žumberak celebrated the patron saint's day of the village chapel.

Another reason for the return of Greek Catholics to Žumberak are the Saturday feasts for the dead. ${ }^{10}$ From 1945 until the early 1980s, the feasts were not observed due to the pressure of the communist regime. ${ }^{11}$ Although the closest relatives of the Greek Catholics who migrated in the cities are buried in the city graveyards, after the revival of the Saturday feasts for the dead, on these days many Greek Catholics also began to visit the graveyards in $\breve{Z}$ umberak where their distant relatives rest. ${ }^{12} \mathrm{~A}$ tour of any of the graveyards in the region shows that the Greek Catholic migrants bestow great care upon them.

The periodical returning is mainly institutionally organized and initiated by the Greek Catholic Church and cultural societies. ${ }^{13}$ In order to ensure the participa-

9 Similar examples are registered among the Orthodox Christian population in Bulgaria and Macedonia; seе: Боцев 2001; Периклиева 2015; Hristov 2007: 247-260.

10 The Greek Catholics honour the dead five times per year - following the Eastern and the Western rite.

11 Their revival in the 1980s is related to an alleged miracle which occurred in the Greek Catholic cathedral in Križevci: "Another miracle happened thirty years ago in the cathedral in Križevci. The nuns were attending a liturgy when they heard a bang coming from the roof. They ran outside and saw flames on the roof. They called the fire-brigade but when the firemen came they saw no fire. The bishop took that as a sign that the Saturday feasts for the dead should be revived. Until then they weren't observed, as they had been discontinued. Now we have four Saturday feast for the dead. [...] When we didn't celebrate the Saturday feasts for the dead, we honoured the dead only on All Saints' Day. They were discontinued after 1945 when the partisans came" (T. R., male, 51 y/o, lives in Zagreb).

12 In 2012, Violeta Periklieva observed one of the Saturday feasts for the dead in Žumberak.

13 The two types of institutions play a leading part in the process of construction and maintaining of local (respectively religious) identity of the Greek Catholics from Žumberak. This is not a surprise having in mind that the main figures of the initiative in the Church (the Bishop of Križevci Nikola Kekić, the vicars Father Danijel Vranešić in Samobor and Father Mile Vranešić in Stojdraga) were born and raised in Žumberak, in a family of priests. The efforts of the Church along these lines have increased during the last fifteen years, but were especially tangible in 2012 when it celebrated the $400^{\text {th }}$ anniversary of the establishment of the Bishopric of Križevci: "During the last ten years, there is a strong process of revitalization of the Greek Catholic Church" (T. R., male, 51 y/o, lives in Zagreb); "The attempts at reviving the identity have already been going on for twenty years, since the democratization and the independence of Croatia. [...] In my opinion, during the war and afterwards, none of the attempts succeeded. [...] People continued to dissociate themselves from the Bishopric of Križevci because of the Eastern rite, and to renounce their Žumberak and Greek Catholic identity. [...] There are people from the Church - part of the priests from Žumberak whose main aim is to revive the Uskok identity. [...] We'll see what the future will bring. I have the 
tion of as many members of the community as possible, the Church even shifts the patron saint's days and other religious events to the closest Sunday after the exact day.

Besides calling the Greek Catholics to return, special efforts are invested on the part of the Church for the revival of extinct or dying religious customs, i.e. for the reconstruction/invention of tradition (following Hobsbawm 1983) based exclusively on the Byzantine rite. A typical example of such a process is the attempt to revive the family custom of krsna slava, i.e. the family feast of the patron saint of the family group. The Church is circulating special leaflets among the internal and external migrants describing how to perform the rite of krsna slava and what its meaning for the communal identity is. The vicar in Samobor keeps a special book with a file for each family, including also the day of the saint in which krsna slava is celebrated by each family. The head of the family which does not celebrate its krsna slava is summoned by the priest for a personal conversation, aiming to revive the neglected custom. In 2014, a list of the family names of the Greek Catholics from Žumberak and of the patron saints of their krsna slava appeared on the website of the Vicariate of Žumberak ${ }^{14}$ so that every member of the scattered community has access to it. As a result, there are already families of internal as well as of some external migrants who have resumed the celebration of the custom. ${ }^{15}$

Whenever the Church is not successful in reviving old customs, it recourses to other strategies that once again lead to changes in the custom. It introduces religious family customs within the temple of the church, for example krsna slava and Napijanje u Slavu Božju. On the day of the festival of a saint known to be the patron of some Žumberak families, the Bishop performs for the representatives of the respective families in the church the toast Napijanje u Slavu Božju, typical of the ritual. In this case, the pattern of the krsna slava is taken out of its family context and introduced in the church service where, in the form of an institutionalized collective ritual meant for the whole community, it changes its function: from a ritual aiming at sustaining unity at a family level into a ritual establishing local consciousness.

Another characteristic process, which is also an initiative on the part of the Church, is the acquisition of visual symbols of local identity. One of these symbols is the so-called icon of Žumberačka Bogorodica or the Virgin Mary of Žumberak (Figure 1) by means of which the Greek Catholic community from Žumberak

feeling that more and more young people are becoming interested in their Žumberak origin...” (J. Š., male, 40 y/o, lives in Stojdraga, Žumberak).

14 https://www.zumberacki-vikarijat.com/krsne-slave-zumberackih-uskoka/ (last access 16 November 2017).

15 "Today, this custom is rarely observed. Thanks to Danijel [Father Danijel Vranešić] some families began to celebrate it again" (T. R., male, 51 y/o, lives in Zagreb). 
symbolizes its connection with their migrant ancestors. The story goes that the icon was brought by the uskoci in their migration. The icon's symbolism draws parallels between the Virgin Mary's pain for the Crucified Christ and the pain of the Žumberak mothers during the Military Frontier who mourned over their dead husbands and sons. ${ }^{16}$ According to some sources, the original is nowadays kept "under lock and key" in the Greek Catholic Seminary in Zagreb and its replicas are placed in the majority of churches in Žumberak and the cities with migrant communities. One can also find reproductions of the icon in many homes in $\check{Z}$ umberak, and there are cases in which migrant members of the community abroad carry the Virgin Mary of Žumberak with themselves. The icon is also almost constantly present at religious processions in the country and abroad where there are members of the Greek Catholic community.

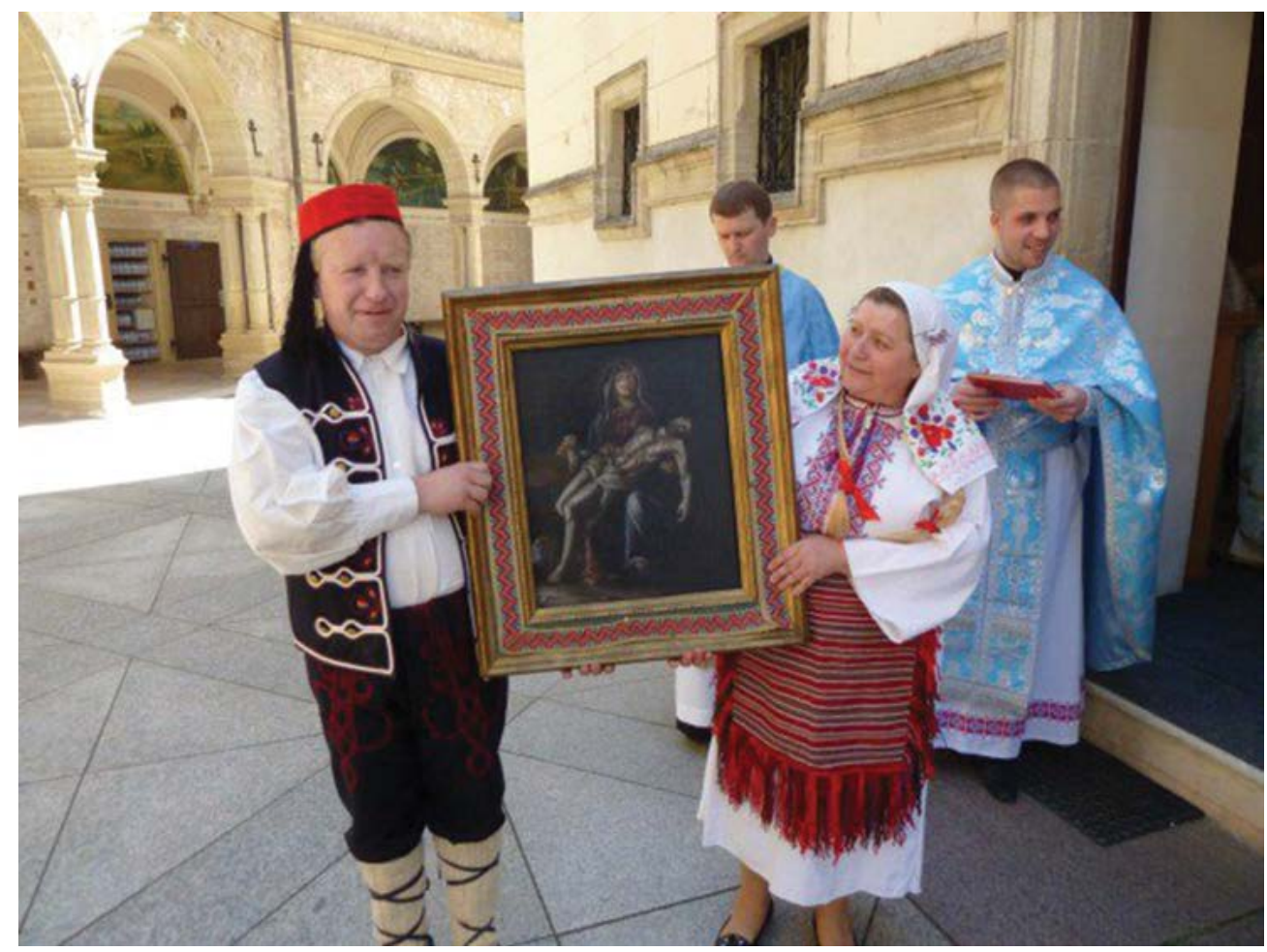

Figure 1: The icon of the Virgin Mary of Žumberak, Marija Bistrica, Croatia (April 2012). Photographer: Violeta Periklieva.

16 "They [the Uskoks] had brought the icon with them in order to remind them of their homeland. [...] According to the symbolic of the icon, in the same way after the wars the Uskok mothers mourned over their dead sons and husbands" (J. Š., male, 40 y/o, lives in Stojdraga, Žumberak). 


\section{Temporary labour migration of the Orthodox Christians from Eastern Serbia and Western Macedonia}

Traditional patterns of trans-border seasonal labour mobility involving the majority of the male population of entire regions have existed in the Balkans for centuries. The main principle was that men earned "there" (in the city or abroad) but fed their families "here", in the home villages. This century-long traditional

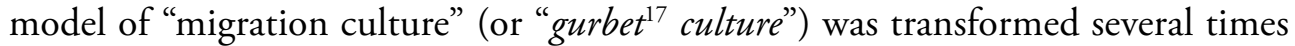
during the $20^{\text {th }}$ century. The new political borders set in the Balkans after the Balkan Wars and the First World War, the policy of mobility restrictions implemented by the different nation states, the political ideology of nationalism and the social environment in most of the Balkan countries, as well as the increasing national propaganda against ethnically and religiously "foreign" people led to the intensive decrease in the cross-border labour mobility of men (cf. BaldwinEdwards et al. 2015: 5-11). In the interwar period, the labour market for seasonal cross-border migrants in the Balkans was in collapse. This led to a change in the pattern of male labour mobility - its destinations were re-directed towards the big cities within the respective country. However, this mobility pattern still had the traditional characteristics of temporary labour - men were earning in the city but their families stayed in their home villages, where the men returned to spend the inactive winter months.

The nature of labour migrations, their destinations and intensiveness changed once more during the 1960s, when countries in Western Europe began hiring legal guest workers (Gastarbeiters) from Yugoslavia. The need for labour force in countries like Switzerland and Germany led to a series of agreements and engagement of workers from Yugoslavia in many countries of Western Europe. This type of migratory movements toward Western European countries reached its climax in the early 1970s when, owing to the laws for bringing families together, a significant part of male Gastarbeiters settled in the host countries, thus transforming them into countries of immigration. These migratory processes became more frequent during the 1990s (the "decade of transition"), when countries like Albania, Bulgaria and Romania joined these processes. In this way, the above-mentioned traditional gurbet model of seasonal migrations and labour outside the region (see Hristov 2015: 30-46) was transformed from the beginning of the 1970s into the pechalbar's model of the Gastarbeiter culture (cf. in details Ivanović 2012).

17 The labour mobility is known in different Balkan languages as gurbet / kurbet / kurbéti, or through the South-Slavic term pečalbarstvo. The word "gurbet" in most Balkan languages comes from the Turkish-Arabic "gurbet", meaning "abroad" (see Турско-български речник 1952: 193), and the South-Slavic word "pečalbarstvo", from the Slavic "pečalba" ("gain"), i.e. to "gain for a living" (see Hristov 2015: 31). 
Today, many of these pechalbar's villages have already been deserted. Nevertheless, nostalgia for home still remains - near the end of their lives, some of these Gastarbeiters return from all over the world to their villages in order to die "at home". Once they return to their native villages after retirement, these people at first renovate their own houses and buy homes in the city nearby. Later, though, the former Gastarbeiters take it as a duty to renovate and continuously preserve the religious (in this case Orthodox Christian) and ritual sacred places of the family and the local community; we observed this in numerous villages in Bulgaria, Serbia and the Republic of Macedonia (Hristov 2012: 287-294). Some Gastarbeiters rebuild old churches and chapels, invest in their interior, resume customs and rituals, etc. There are many examples, but here we will give only two.

In the village of Trgovište, near Knjaževac in Eastern Serbia, which Petko Hristov visited in 2001, a former worker in the Mercedes concern who returned from Germany renovated the family chapel (zavetina) during the 1990s, considering this as an important "obligation" (Figure 2 and 3). According to him, the renovation of the chapel was "his sacred duty to the family tradition and his ancestors". The chapel was built in 1866 and every year the family used to celebrate their slava by the cross. The retired Gastarbeiter not only renovated the chapel but also kept the tradition of holding the family slava near the cross. For comparison - a neglected stone cross and family chapel in the same village (Figure 4).

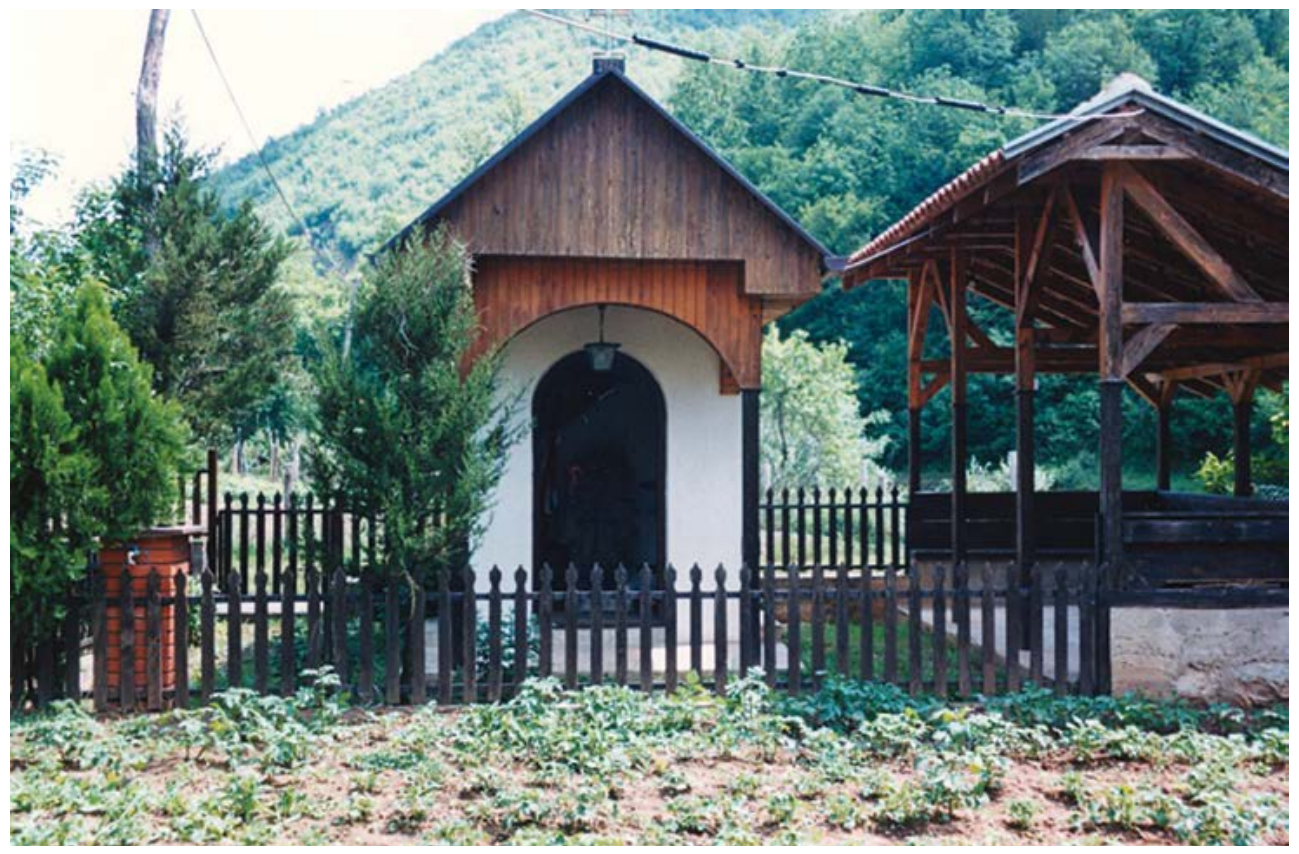

Figure 2: Family chapel restored by a former Gasterbeiter, Trgovište, Serbia (2001). Photographer: Petko Hristov. 


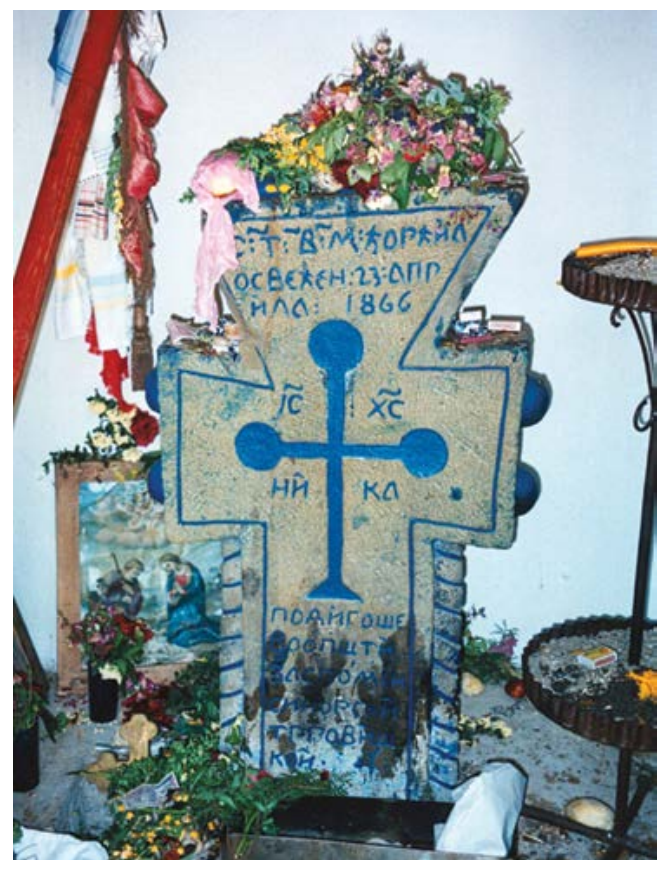

Figure 3: A stone cross in a family chapel restored by a former Gasterbeiter, Trgovište, Serbia (2001). Photographer: Petko Hristov.

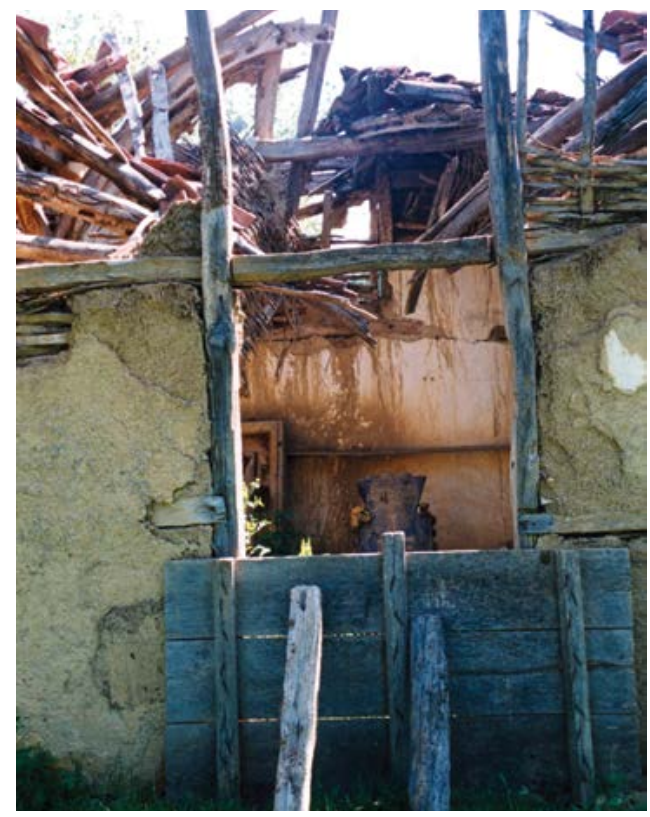

Figure 4: A neglected stone cross and family chapel, Trgovište, Serbia (2001). Photographer: Petko Hristov. 
The second example is from the village of Halovo, near Zaječar (Serbia), which has a Wallachian population; it was visited by Petko Hristov in 2001 and 2012. A Gastarbeiter from the village gold-plated the entire iconostasis in the village church upon returning from Frankfurt (Figure 5). According to his fellow villagers, he did this as an act of gratitude to God that he had managed to earn enough money in Germany and to return to his home village in good health.

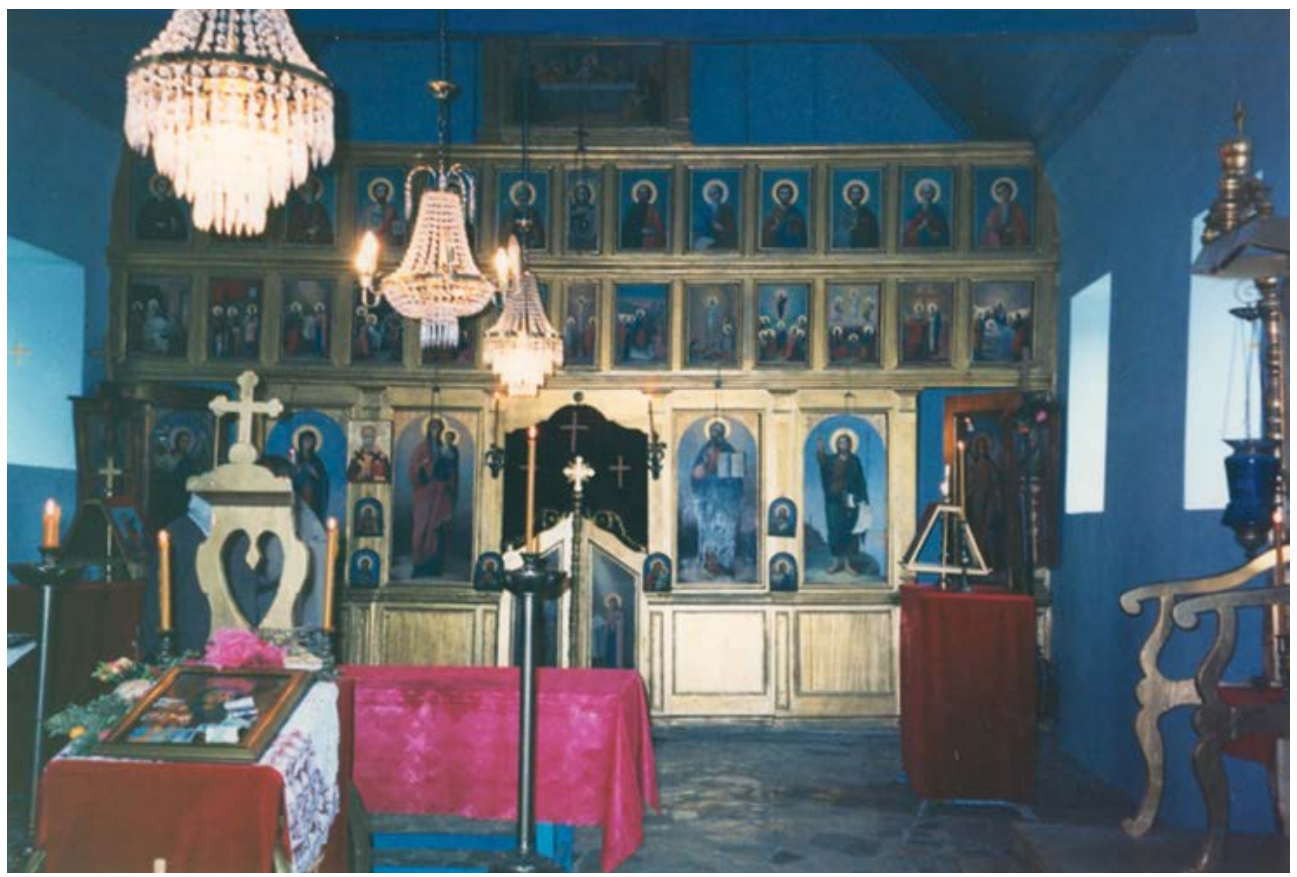

Figure 5: An iconostasis gold-plated by a former Gasterbeiter, Halovo, Serbia (2001). Photographer: Petko Hristov.

Migration also leads to changes in local religiosity. For example, the traditional feast calendar in Vevčani, Western Macedonia, has been transformed in the second half of the $20^{\text {th }}$ century in such a way as to concentrate all important family holidays during the winter months, when men who had a century-long tradition in temporary and seasonal labour migrations to both neighbour Balkan countries and to Germany, Austria and Switzerland were at home. In 2001, a Gastarbeiter who had returned from Germany began renovating a special "pechalbar" chapel high in the mountains. The chapel was dedicated to the Feast of the Ascension (Spasovden, on Thursday, the fortieth day after Easter), but the celebrations were held in January (on the Thursday before St. Athanasius's Day) when the Gastarbeiters returned home for Christmas. According to the local respondents, the celebrations had to ensure good health and success to the men who were working abroad. In this case, the chapel is a typical lieux de mémoire (in the terminology of Pierre Nora; Hopa 
2004, 2005), an important part of the migrants' collective memory and identity (see Hristov 2009).

In other cases, unable to participate in important religious rituals in their home villages, some Gastarbeiters relocate elements of their local religiosity to the receiving country. Thus, for example, some Gastarbeiters from Macedonia who are unable to attend the village kurban $^{18}$ in their home villages sacrifice an animal and give it to neighbouring families in the receiving country in order to take part in the village celebration.

\section{Conclusion}

The cases presented here show that, despite the type of migration (internal or external, permanent or temporary), migrants maintain a strong bond with their local religiosity. At the same time, the context of migration makes a number of changes in local religiosity, adapting it to the new realities either in the place of origin or in the receiving environment. In fact, this adaptation is one of the key processes that Hobsbawm (1983) identifies in the "invention" of tradition - the use of familiar models and traditional ritual patterns for new purposes. The main purpose in this case is the aspiration for self-identification under the conditions of migration. Seeing themselves in "the mirror of otherness" or, as Barth (1969) puts it, entering in interactions with "others", migrants rediscover the strong bond with their birthplaces. For the internal Greek Catholic migrants from Žumberak, this mirror is the Roman Catholic majority in Croatia. For the external permanent or temporary labour migrants from Serbia and Macedonia, this is the multicultural environment in the receiving countries. In both cases, however, one of the instruments that take part in the process of self-identification, local identity construction, and belonging to the local community is local religiosity.

The cases show the importance of local religiosity (as defined in the beginning) and local identity. This suggests that, despite the theories of secularization and globalization, at the same time there are counter-processes running which maintain the role of religiosity and local community in social life. The contradiction of the phenomena in the religious life is presented by Peter Berger as counter-secularization. According to him, secularization on the level of society does not necessarily mean secularization on the level of individual consciousness. Some religious institutions

18 Among the Orthodox Christian population of Bulgaria and the Republic of Macedonia, as well as in some places in Southeastern Serbia and Northern Greece, the custom of making a collective blood sacrifice in honour of the patron saint of the local church is still observed. The term kurban for the sacrificial animal derives from Arabian through the Turkish language, but the prototype is Abraham's sacrifice in the Old Testament; the ritual practice has its roots in the pagan sacrifices in antiquity (cf. in details Hristov and Manova 2007: 211-231; Hristov 2007: 247-260). 
lose their power and influence, but religious beliefs and practices continue to exist in the life of the individuals. At the same time, other religious institutions continue to be socially and politically significant although few people practice the religion related to them (Berger 1999). Similarly, while globalization and intensified mobility lead to gradual loss of significance of the established state borders in Europe and frequent mentions of "European identity", at the same time, perhaps as a counterprocess, new borders appear (after the dissolution of Yugoslavia and the Soviet Union) or struggle to appear (the latest example of Ukraine) and in many countries nationalist movements make their way, gain new adherents and in some cases even put in the agenda the problem of exiting the EU (the French National Front, the Dutch Party of Freedom, the Independence Party in the UK, etc.).

All this brings transformations in national identity. These transformations result in stronger attachment to the local and an increase in the intensification of communal consolidation and self-identification at the local level. In fact, contrary to the traditional idea that national communities represent a "continuation" of ethnic communities, in the pre-national era local identity plays a more important role in the hierarchy of identities than the ethnic (see for example Detrez 2015). Since man seeks identification with less abstract communities, and the local contains the ethnic or national as well as the specific local (Генчев 1984), self-identification at the local level could be an expression and a result of the two opposed processes - globalisation and intensifying nationalism.

Thus, the case studies presented here not only shed light on the problems of the migrants' attitude toward local religiosity and its role in the processes of selfidentification in the context of migration, but also reinforce the need to consider the "laws" to which these processes submit in social life. Do social processes, similarly to Newton's laws, cause counter-processes which, in spite of the contextual changes, seek to maintain certain "balance" in society, such as the preservation of the social role of religiosity and the hierarchal order of identities in which the lowest and respectively most familiar level of self-identification is of paramount importance? 


\section{REFERENCES}

Baldwin-Edwards, Martin, Riki Van Boeschoten and Hans Vermeulen. 2015. "Introduction". In Migration in the Southern Balkans. From Ottoman Territory to Globalized and Nation States. IMISCOE Research. Hans Vermeulen, Martin Baldwin-Edwards and Riki Van Boeschoten, eds. Dordrecht: Springer, 31-46.

Barth, Fredrik. 1969. "Introduction". In Ethnic Groups and Boundaries. The Social Organization of Cultural Difference. Fredrik Barth, ed. Oslo, London: Bergen, Universitetsforlaget, George Allen and Unwin, 9-38.

Berger, L. Peter. 1999. "The Desecularization of the World. A Global Overview”. In The Desecularization of the World. Resurgent Religion and World Politics. Peter L. Berger, ed. Washington: Ethics and Public Policy Center, 1-18.

Боцев, ВАадимир. 2001. “Животот во пустото село Папавница” [Life in the Deserted Village of Papavnitsa]. In The Border. Границата, T. 1. Тошо Спиридонов, ed. София: АИОС, 113-119.

Bourdieu, Pierre. 1971. "Genèse et structure du champ religieux" [Genesis and Structure of the Religious Field]. Revue française de sociologie 12: 295-334.

Čapo Žmegač, Jasna. 2007. "Povratak na granicu. Migracijska iskustva u trokutu Hrvatska-Njemačka-Slovenija” [Return to the Border. Migration Experiences in the Croatia-Germany-Slovenia Triangle]. Dve domovini / Two Homelands 25: 89-108.

Čizmić, Ivan and Nada Hranilović. 1990. Povijest hrvatske naseobine u Clevelandu, Ohio (1880-1930) [History of the Croatian Settlement in Cleveland, Ohio (18801930)]. Zagreb: Institut za migracije i narodnosti Sveučilišta u Zagrebu.

Cohen, Anthony. 1985. The Symbolic Construction of Community. London, New York: Routledge.

Detrez, Raymond. 2015. "Reassessing Ethnic Identity in the Pre-National Balkans". In Contextualizing Changes. Migrations, Shifting Borders and New Identities in Eastern Europe. Petko Hristov, Anelia Kassabova, Evgenia Troeva and Dagnosław Demski, eds. Sofia: Paradigma, 433-442.

Аюркем, Емик. 1998. Елементарни форми на религиозния живот [The Elementary Forms of Religious Life]. София: София С. А.

Gagnon, Chip V. P. 1997. "Imaginings of the Frontier. Nations of Borders and Groupness”. In Frontiers. The Challenge of Interculturality. Božidar Jakšić, ed. Beograd: Forum za etničke odnose, 47-61.

Geertz, Clifford. 1973. The Interpretation of Cultures. Selected Essays. New York: Basic Books.

Генчев, Стоян. 1984. Народна култура и етнография [Folk Culture and Ethnography]. София: Наука и изкуство.

Hobsbawm, Eric. 1983. "Introduction". In The Invention of Tradition. Eric Hobsbawm and Terence Ranger, eds. Cambridge: Cambridge University Press, 1-14. 
Христов, Петко. 2004. “Границите на 'Шопмука' и/ими шопи без граници” [Тhe Borders of the "Shopluk Region" and/or Shops without Borders]. In Скривене матине на Балкану. Бињана Сикимић, еd. Београд: Балканолошки институт, 67-82.

Hristov, Petko. 2007. "Celebrating the Abandoned Village. The Ritual Process in the Post-Socialist Balkans". In Kurban in the Balkans. Biljana Sikimić and Petko Hristov, eds. Belgrade: Institute for Balkan Studies, 247-260.

Hristov, Petko and Tsvetana Manova. 2007. "The New 'Old' Kurban. A Case Study”. In Kurban in the Balkans. Biljana Sikimić and Petko Hristov, eds. Belgrade: Institute for Balkan Studies, 211-231.

Hristov, Petko. 2009. "Gurbet Toponymy”. Македонски фолклор 67: 91-96.

Hristov, Petko. 2010. "Trans-Border Migration. The Example of Western Macedonia”. In Migrations from and to Southeastern Europe. Anna Krasteva, Anelia Kasabova and Diana Karabinova, eds. Ravenna: Longo Editore, 141-150.

Hristov, Petko. 2012. "Religious Markers of Identity in the Context of Labour Mobility in Western Macedonia, Bulgaria and Eastern Serbia". In Religion, Religious and Folk Customs on the Border. Dragoljub B. Đorđević, Danijela Gavrilović and Dragan Todorović, eds. Niš: Junir, 287-294.

Hristov, Petko. 2015. "The Balkan Gurbet. Traditional Patterns and New Trends". In Migration in the Southern Balkans. From Ottoman Territory to Globalized and Nation States. IMISCOE Research. Hans Vermeulen, Martin Baldwin-Edwards and Riki Van Boeschoten, eds. Dordrecht: Springer, 31-46.

Ivanović, Vladimir. 2012. Geburtstag pišěs normalno. Jugoslovenski gastarbajteri u SR Nemačkoj i Austriji 1965-1973 [You Write Geburtstag Normally. Yugoslav Guest Workers in the Federal Republic of Germany and Austria 1965-1973]. Beograd: Institut za savremenu istoriju.

Kaser, Karl. 1997a. Slobodan seljak i vojnik, 1. [Free Peasant and Soldier, 1]. Zagreb: Naprijed.

Kaser, Karl. 1997b. Slobodan seljak i vojnik, 2. [Free Peasant and Soldier, 2]. Zagreb: Naprijed.

Mal, Josip. 1924. Uskočke seobe i slovenske pokrajine. Povest naseobina s kulturno-istorijskim prikazom (sa kartom). Srpski etnografski zbornik. Knjiga XXX. Prvo odelenje. Naselja $i$ poreklo stanovnistva. Knjiga 18 [Uskok Migrations and Slovenian Provinces. History of Settlements with a Historical and Cultural Review (with a Map). Serbian Ethnographic Collection. Book XXX. Section One. Settlements and Origin of the Population. Book 18]. Ljubljana: Jugoslavanska tiskara.

Marcus, E. George. 1995. "Ethnography in/of the World System. The Emergence of Multi-Sited Ethnography”. Annual Review of Anthropology 24: 95-117.

Muraj, Aleksandra. 1989. Živim znači stanujem. Etnološka studija o kulturi stanovanja u žumberačkim Sošicama [Living Means Dwelling. Ethnological Study on the Culture of Dwelling in Sošice, Žumberak]. Zagreb: Hrvatsko etnološko društvo.

Нора, Пиер. 2004. Места на памет, 1. Oт републиката до наиията [Places of Memory, 1. From the Republic to the Nation]. София: Аом на науките за човека и обществото. 
Нора, Пиер. 2005. Места на памет, 2. От архива до емблемата [Places of Memory, 2. From the Archive to the Symbol]. София: Аом на науките за човека и обществото.

Periklieva, Violeta and Petko Hristov. 2013. "Local Religion and Strategies for Identity Development. Greek Catholics from the Region of Žumberak, Croatia”. Monitor ISH 15/1: 19-44.

Перикмиева, Виолета. 2015. “Механизми за трансформация на мокалния ремигиозен пейзаж в региона на граА Петрич” [Mechanisms for Transformation of the Local Religious Landscape in the Region of Petrich]. Българска етнология 1: 47-61.

Турско-български речник [Turkish-Bulgarian Dictionary]. 1952. София: Бъмгарска академия на науките.

Въцчинова, Галина. 1999. Знеполски похвали. Аокална религия и идентичност в Западна България [Znepole Praises. Local Religion and Identity in Western Bulgaria]. София: АИ “Проф. Марин Аринов”.

Въцчинова, Галина. 2006. Балкански ясновидки и пророчици от XX век [Balkan Clairvoyants and Prophetesses of the 20 $0^{\text {th }}$ Century]. София: УИ “Св. КАимент Охридски". 